\title{
GMR
}

\section{Genetic parameters for carcass traits and body weight using a Bayesian approach in the Canchim cattle}

\author{
S.L.C. Meirelles ${ }^{1}$, F.B. Mokry ${ }^{2}$, A.C. Espasandín ${ }^{3}$, M.A.D. Dias ${ }^{1}$, \\ M.M. Baena ${ }^{1}$ and L.C. de A. Regitano ${ }^{4}$ \\ ${ }^{1}$ Departamento de Zootecnia, Universidade Federal de Lavras, \\ Lavras, MG, Brasil \\ ${ }^{2}$ Departamento de Genética e Evolução, Universidade Federal de São Carlos, \\ São Carlos, SP, Brasil \\ ${ }^{3}$ Department of Animal and Forage Production Science, \\ University of the Republic-School of Agronomy-EEMAC, Paysandú, Uruguay \\ ${ }^{4}$ Embrapa Pecuária Sudeste, São Carlos, SP, Brasil \\ Corresponding author: S.L.C. Meirelles \\ E-mail: sarahlcmeirelles@gmail.com
}

Genet. Mol. Res. 15 (2): gmr.15027471

Received August 18, 2015

Accepted May 12, 2016

Published June 10, 2016

DOI http://dx.doi.org/10.4238/gmr.15027471

\begin{abstract}
Correlation between genetic parameters and factors such as backfat thickness (BFT), rib eye area (REA), and body weight (BW) were estimated for Canchim beef cattle raised in natural pastures of Brazil. Data from 1648 animals were analyzed using multi-trait (BFT, REA, and BW) animal models by the Bayesian approach. This model included the effects of contemporary group, age, and individual heterozygosity as covariates. In addition, direct additive genetic and random residual effects were also analyzed. Heritability estimated for BFT (0.16), REA (0.50), and BW (0.44) indicated their potential for genetic improvements and response to selection processes. Furthermore, genetic correlations between $\mathrm{BW}$ and the remaining traits were high $(\mathrm{P}>0.50)$, suggesting that selection for BW could improve REA and
\end{abstract}


BFT. On the other hand, genetic correlation between BFT and REA was low $(P=0.39 \pm 0.17)$, and included considerable variations, suggesting that these traits can be jointly included as selection criteria without influencing each other. We found that REA and BFT responded to the selection processes, as measured by ultrasound. Therefore, selection for yearling weight results in changes in REA and BFT.

Key words: Animal selection; Backfat thickness; Cattle; Composite breed; Rib eye area

\section{INTRODUCTION}

Brazil is the largest beef exporting country in the world, and to remain so, will need to maintain a continuous supply of quality products as well as gaining new ones. Many traits are involved in determination of meat quality, such as rib eye area (REA) and backfat thickness (BFT), which are used as selection criteria in many cattle breeding programs in Brazil.

However, before including these traits in breeding programs, it is necessary to understand their genetic variability. The greater the genetic variability of a trait in the population, the greater is its response to selections. This concept can be applied to maximize the genetic potential for production of high quality meats.

Canchim (5/8 Charolais $+3 / 8 \mathrm{Zebu})$ is a Brazilian beef cattle breed developed in the early 60's. They have adapted to the tropical climate of Brazil, and can be raised on natural pastures. Moreover, this breed shows good growth potential with desirable meat quality. Currently, there are four possible crossing schemes for obtaining Canchim animals; each scheme results in a slight difference (around 7\%) in the percentages of Charolais and Zebu traits in the offspring. According to Barichello et al. (2011), these differences are a source of variation for growth traits, and should be accounted for in the statistical model by including the contribution of each breed, and their individual levels of heterozygosity.

The main advantage of crossbreeding and composite breeds is the ability to obtain high genetic progress by joining desirable traits of two or more breeds into a single animal. This takes advantage of heterosis, which is a genetic phenomenon that induces higher proportion of the trait of interest in the offspring than in the parents. According to Hohenboken (1985), this degree of superiority varies in accordance with the degree of maternal and individual heterozygosis, the genetic distance between breeds crossed, the gene frequencies in the base populations, and the specific traits considered.

Estimation of population genetic parameters provides information regarding trait inheritance, and establishes the basis for choosing the most appropriate approaches to improve productivity. Therefore, the aim of this study was to estimate heritability and genetic parameters that influences rib eye area, backfat thickness, and body weight for Canchim cattle using a Bayesian inference approach.

\section{MATERIAL AND METHODS}

\section{Data set}

Records from 1648 half-sib offspring (776 males and 872 females) derived from 152 
sires, were born between 2003 and 2008. They were raised as seven herds on pasture from the Brazilian states of Goiás and São Paulo, and were part of the Canchim Cattle Breeding Program. BW, REA, and BFT were measured from 2005 to 2010 in Canchim animals raised on high quality natural pasture.

REA $\left(\mathrm{cm}^{2}\right)$ and BFT $(\mathrm{mm})$ were obtained through cross-sectional imaging of the Longissimus muscle between the 12 and 13th ribs. An ALOKA 500V (Corometrics Medical Systems Inc., Wallingford, CT, USA) apparatus equipped with a $3.5-\mathrm{MHz}, 17.2-\mathrm{cm}$ linear transducer (Aloka Co. Ltd., Tokyo, Japan) as well as an acoustic coupler (standoff pad) was used to obtain RTU images. Images were stored on an image capture system (Black box, Biotronics, Ames, IA, USA), and subsequently analyzed.

Ultrasound measurements, as well as BW determinations, were performed in animals between the months of February and April each year. The animals ranged from 15 to 26 months of age.

\section{Statistical models of genetic analysis}

Fixed effects to be considered in the analysis model were chosen after determining their statistical significance $(\mathrm{P}<0.05)$ with a linear fixed effects model via the GLM procedure of SAS (SAS, 2010).

A multi-trait analysis including REA, BFT, and BW was conducted on the environmental and genetic effects that exerted influence on our traits of interest to estimate the (co)variance components used to calculate heritability and genetic correlations. The animal model included fixed effects of contemporary groups (CG), linear covariates of the animal's age at the time of measurement and animal heterozygosity (Barichello et al., 2011), as well as additive direct genetic and random residual effects. Contemporary groups were obtained by combining year of birth, herd, and sex, yielding 31 distinct contemporary groups. Only animals with measurements in at least two traits and a $C G$ value of more than five animals were considered in the analysis.

Animal-retained heterozygosity was calculated according to the formula:

$$
H=\sum S i(1-D i) \quad \text { (Equation 1) }
$$

in which $\mathrm{Si}=$ fraction of the breed $\mathrm{i}$ (either Charolais or zebu) in the sire; $\mathrm{Di}=$ fraction of the breed $\mathrm{i}$ (either Charolais or zebu) in the dam, as described by Dickerson (1973).

Marginal posterior distributions of (co)variance components and heritability for BW, REA and BFT were estimated by Bayesian inference using the Gibbs sampling method (Misztal et al., 2002). Gibbs chains of 2,550,000 iterations were generated for each parameter, with a burn-in period of 50,000 iterations, and a sampling interval of 500 iterations. There were a total of 4900 independent samples for Maximum a posteriori estimates. Convergence of the Gibbs sampling chain to a stationary distribution was diagnosed using the Heidelberger and Welch (1981) method, as described by Cowles et al. (1995). The CODA package (Plummer et al., 2006) was used, which was implemented in the R library [R Development Core Team (2012), version 2.13.2 - 2012].

A flat (non-informative) Maximum a priori distribution was defined for fixed effects $(\beta)$, and an inverse Wishart distribution was assumed for the genetic and residual (co)variance 
components. This type of Maximum a priori distribution was expected to provide dominant data, i.e., the Maximum a priori information has little influence on the estimates (Meirelles, et al., 2009).

The statistical model used was:

$$
y=X \beta+Z u+e
$$

(Equation 2)

where: $y=$ vector of observations; $\beta=$ vector of fixed effects (contemporary group and covariates); $\mathrm{u}=$ vector of direct additive genetic effect; $\mathrm{e}=$ vector of random residual errors associated with the observations; $\mathrm{X}$ and $\mathrm{Z}=$ incidence matrices for each effect.

The $95 \%$ credibility region (CR) used in the Bayesian analysis was achieved by eliminating the lowest $2.5 \%$ and the highest $2.5 \%$ in the Maximum a posteriori parameter distributions.

The genetic parameters were estimated using the following formulas:

$$
\begin{gathered}
h_{i}^{2}=\sigma_{g a_{i}}^{2} / \sigma_{f e n_{i}}^{2} \\
r_{i ; j}=\operatorname{Cov}_{i ; j} /\left(\operatorname{sqrt}\left(\sigma_{g a_{i}}^{2}\right)^{*} \operatorname{sqrt}\left(\sigma_{g a_{i}}^{2}\right)\right)
\end{gathered}
$$

where $\sigma_{g a i}^{2}$ and $\sigma_{\text {feni }}^{2}=$ additive genetic variance and phenotypic variance for each $i$ trait; $h^{2}$ $=$ heritability of the trait $i ; \operatorname{Cov}_{\mathrm{i} ; \mathrm{j}}=$ covariance between direct genetic effects between $i$ and $j$ traits; $r_{i, j}=$ correlation between the direct additive genetic effects of traits $i$ and $j$.

\section{RESULTS}

Phenotypic mean values for REA, BFT and BW were similar to those reported by Meirelles et al. (2010) (Table 1), which was not completely unexpected as the population in the previous study was incorporated within this data set. Compared to results by Meirelles et al. (2010), the REA trait presented a slightly higher variation coefficient, due to the increase in its range (minimum of 19.91 to a maximum of $82.80 \mathrm{~cm}^{2}$ ) in this study, while BFT and BW show similar values in descriptive statistics (Table 1).

Table 1. Descriptive statistics for rib eye area, backfat thickness, and body weight in Canchim cattle.

\begin{tabular}{l|c|c|c|c|c}
\hline Trait & N & Mean $(\mathrm{SD})$ & CV & Minimum & Maximum \\
\hline REA $\left(\mathrm{cm}^{2}\right)$ & 1648 & $47.50(9.86)$ & 20.74 & 19.91 & 82.80 \\
\hline BFT $(\mathrm{mm})$ & 1648 & $2.13(0.78)$ & 36.77 & 0.60 & 5.40 \\
\hline BW $(\mathrm{kg})$ & 1611 & $318.78(58.62)$ & 17.95 & 163.00 & 564.00 \\
\hline
\end{tabular}

$\mathrm{SD}=$ standard deviation; $\mathrm{CV}=$ coefficient of variation; $\mathrm{REA}=$ rib eye area; $\mathrm{BFT}=$ backfat thickness; $\mathrm{BW}=\mathrm{body}$ weight.

The maximum a posteriori mean, mode and median heritability estimates for all traits did not converge to the same value (Table 2), which was an indicator of symmetric distribution. 
However, the values were similar, and the maximum a posteriori heritability distributions for these traits were very close to a normal distribution, as shown in Figure 1. According to Gianola and Foulley (1990), when the maximum a posteriori mean, mode, and median estimates differ, the mode is considered the most accurate estimate in the Bayesian inference context. Therefore, we assumed heritabilities of 0.44 for BW, 0.50 for REA, and 0.16 for BFT.
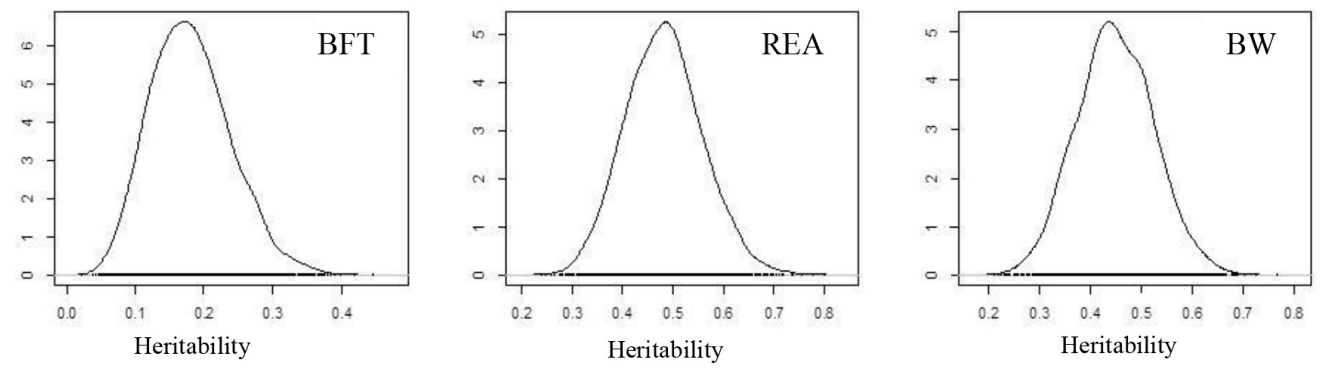

Figure 1. Maximum a posteriori heritability estimate distributions for backfat thickness (BTF), rib eye area (REA), and body weight (BW) in Canchim cattle from 4900 samples.

Table 2. Maximum a posteriori estimates of mean, mode, median and $95 \% \mathrm{CI}$ for heritabilities of $\mathrm{BW}$, REA and BFT in Canchim cattle.

\begin{tabular}{l|c|c|c|c}
\hline Trait & Mean & Mode & Median & $95 \%$ CI \\
\hline BW $(\mathrm{kg})$ & $0.45( \pm 0.08)$ & 0.44 & 0.45 & 0.31 to 0.60 \\
\hline REA $\left(\mathrm{cm}^{2}\right)$ & $0.48( \pm 0.08)$ & 0.50 & 0.48 & 0.33 to 0.63 \\
\hline BFT $(\mathrm{mm})$ & $0.18( \pm 0.06)$ & 0.16 & 0.18 & 0.07 to 0.29 \\
\hline CI
\end{tabular}

$\mathrm{CI}=$ confidence interval; $\mathrm{BW}=$ body weight REA = rib eye area; $\mathrm{BFT}=$ backfat thickness.

Genetic correlations between BW and the remaining traits were high (Table 3) for the Canchim population.

The genetic correlation between REA and BFT was lower, and demonstrated high variability. This should be taken into account while designing a breed improvement program. The environmental correlations between BFT and BW, and between BFT and REA, were close to zero, indicating that environmental factors acting on BFT do not influence the development of BW and REA (Table 3). However, results from environmental correlation suggested that some environmental factors affects both REA and BW in the same direction.

Table 3. Estimates of genetic (above the diagonal) and environmental (below the diagonal) correlations for BW, REA, and BFT in Canchim cattle.

\begin{tabular}{l|c|c|c}
\hline Trait & BW & REA & BFT \\
\hline BW & - & $0.68( \pm 0.08)$ & $0.54( \pm 0.18)$ \\
\hline REA & $0.39( \pm 0.08)$ & - & $0.39( \pm 0.17)$ \\
\hline BFT & $0.12( \pm 0.07)$ & $0.05( \pm 0.07)$ & - \\
\hline
\end{tabular}

$\mathrm{BW}=$ body weight; $\mathrm{REA}=$ rib eye area; $\mathrm{BFT}=$ backfat thickness.

The individual heterozygosity in this Canchim population ranged from 0.54 to 0.65 , and the estimated linear regression coefficient $(b)$ for BFT $(b=1.74)$, REA $(b=37.41)$, and $\mathrm{BW}(\mathrm{b}=410.72)$ indicated that animals with a higher proportion of individual heterozygosity 
(inside the studied heterozygosity range) also demonstrated higher values for BFT, REA, and BW.

\section{DISCUSSION}

This study confirms and further advances results of a previous report by Meirelles et al. (2010) by increasing the number of phenotypes evaluated for determining the reliability of genetic parameters in estimating of carcass traits of pasture-raised Canchim cattle. Additionally, our study assessed preferable genotypes for fast improvement of these traits based on the individual heterozygosity, which would allow farmers to choose which Canchim cross system would deliver the most desirable animal.

In addition, Yokoo et al. (2008) and Zuin et al. (2012) obtained similar phenotypic mean values for REA (48.38 and $52.93 \mathrm{~cm}^{2}$, respectively), and BFT (1.93 and $2.58 \mathrm{~mm}$, respectively) while studying Nellore cattle between 15 and 19 months of age. However, another study examining Canchim cattle raised in a feedlot system showed higher phenotypic mean values for REA $\left(91.30 \mathrm{~cm}^{2}\right)$ and BFT $(5.00 \mathrm{~mm})$, suggesting that the Canchim breed also responds well a feedlot system (Rubiano et al., 2009).

In this study, the heritability estimated for BFT $(0.16)$ was slightly lower than that previously reported by Meirelles et al. (2010), but was still within its estimated heritability range. Zuin et al. (2012) reported a similar heritability value of 0.21 , while Yokoo et al. (2008) reported a higher value of 0.52 for BFT. Both studies were carried out in Nellore animals raised either on pasture or on pasture with mineral supplementation. These moderate values for BFT heritability suggested that subcutaneous fat assessed by ultrasound measurements at yearling and post yearling ages can be used to estimate breeding values in Brazilian Canchim populations. Likewise, this trait can be used as a direct selection criterion to improve Canchim beef quality.

The estimated heritability for REA (0.50) was slightly higher than that previously reported by Meirelles et al. (2010). This difference may be due to the increased number of animals evaluated in our study, which can increase genetic variability. Furthermore, the previous study used a different animal model under a frequentist approach. In the literature, it is possible to find heritability estimates for REA ranging from 0.29 to 0.64 (Reverter et al., 2000; Yokoo et al., 2008; Barbosa et al., 2010; Zuin et al., 2012) in Nellore (Brazil), Angus, and Hereford (Australia) populations. The wide range of heritability estimates for REA may be due to a variety of factors, such as the number of animals evaluated (from approximately 1000 to 12,000), the effects included in the statistical model, environment differences, breedspecific genetic differences, and herd management. Nonetheless, selection for REA should yield fast genetic progress due to its high heritable proportion.

Previous studies in Canchim cattle reported heritability for BW ranging from 0.23 to 0.54 (Alencar et al.,1993; Mascioli et al., 1996; Meirelles et al., 2010; Borba et al, 2011), which was similar to the heritability estimated in this study (0.44). Our results also agreed with a number of studies investigating heritability of growth traits, which showed that these traits have moderate to high heritability in most beef cattle breeds (Marshall, 1994; Gregory et al., 1995; Utrera and Van Vleck, 2004).

The genetic correlations between BW and the remaining traits this study suggesting that selection for BW could improve both REA and BFT. However, other studies also showed 
high genetic correlation between BW and frame size (Horimoto et al., 2007), which could lead to selection of animals with higher maintenance requirements (Ferrell and Jenkins, 1985).

The individual heterozygosity in this Canchim population enables producers to favor animals with higher heterozygosity levels as a strategy for faster genetic improvement of BFT, REA, and BW. As BFT demonstrates low heritability, it is advantageous to implement this selection system. There were no previous studies conducted on individual heterozygosity in Canchim animals, however, Barichello et al. (2011) reported the influence of individual and maternal proportion of Charolais, as well as the positive effects of maternal heterozygosity on weaning traits in Canchim cattle.

In this study, we found that rib eye area and backfat thickness responded to genetic improvement, and that selection for yearling weight could result in increases in rib eye area and backfat thickness. The levels of individual heterozygosity should be taken into account while analyzing Canchim data. These findings should be utilized by the Brazilian Canchim Breeders Association in order to obtain animals with better carcass composition in their genetic breeding programs.

\section{Conflicts of interest}

The authors declare no conflict of interest.

\section{ACKNOWLEDGMENTS}

The authors wish to thank the producers of the Canchim breed Association and the Embrapa Southeast-Cattle Research Center for providing phenotype data used in this study. We also thank CAPES (Coordenação de Aperfeiçoamento de Pessoal de Nível Superior) and CNPq (Conselho Nacional de Desenvolvimento Científico e Tecnológico) for providing scholarships and project financing.

\section{REFERENCES}

Alencar MM, Barbosa PF, Barbosa RT and Vieira RC (1993). Parâmetros genéticos para peso e circunferência escrotal em touros da raça Canchim. Rev. Soc. Bras. Zootec. 22: 572-583.

Barbosa V, Magnabosco CU, Trovo JBF, Faria CU, et al. (2010). Estudo genético quantitativo de características de carcaça e perímetro escrotal, utilizando inferência bayesiana em novilhos Nelore. Biosci. J. 26: 789-797.

Barichello F, Alencar MM, Torres Júnior RAA and Silva LOC (2011). Efeitos ambientais e genéticos sobre peso, perímetro escrotal e escores de avaliação visual à desmama em bovinos da raça Canchim. Rev. Bras. Zootec. 40: 286-293 http:// dx.doi.org/10.1590/S1516-35982011000200008.

Borba LHF, Rey FSB, Silva LOC, Boligon AA, et al. (2011). Parâmetros genéticos para características de crescimento e reprodução de bovinos da raça Canchim. Pesq. Agropec. Bras. 46: 1570-1578 http://dx.doi.org/10.1590/S0100204X2011001100020.

Cowles MK, Best N and Vines K (1995). Convergence diagnostics and output analysis.Version 0.40. MRC Biostatistics, London.

Dickerson GE (1973). Inbreeding and heterosis in animals. In: Proceedings of the animal breeding and genetics symposium in honor of Dr. Jay L. Lush. American Society of Animal Science. Champaign, Illinois, 54-77.

Ferrell CL and Jenkins TG (1985). Cow type and the nutritional environment: nutritional aspects. J. Anim. Sci. 61: 725-741.

Gianola D and Foulley JL (1990). Variance estimation from integrated likelihoods (VEIL). Genet. Sel. Evol. 22: 403-417. http://dx.doi.org/10.1186/1297-9686-22-4-403

Gregory KE, Cundiff LV and Koch RM (1995). Genetic and phenotypic (co)variances for growth and carcass traits of purebred and composite populations of beef cattle. J. Anim. Sci. 73: 1920-1926. 
Heidelberger P and Welch PD (1981). A spectral method for confidence interval generation and run length control in simulations. Commun. ACM 24: 233-245. http://dx.doi.org/10.1145/358598.358630

Hohenboken WD (1985). Genetic structure of populations. In: General and quantitative genetics (Chapman AB eds.). Elsevier Science Ltd., Amsterdam, 251-274.

Horimoto ARVR, Ferraz JBS, Balieiro JCC and Eler JP (2007). Phenotypic and genetic correlations for body structure scores (frame) with productive traits and index for CEIP classification in Nellore beef cattle. Genet. Mol. Res. 6: 188-196.

Misztal I, Tsuruta S, Strabel T, Auvray B, et al. (2002). Blupf90 and related programs (BGF90). In: Proceedings of 7th World Congr. Genet. Appl. Livest. Product., Montpellier, 1-2.

Marshall DM (1994). Breed differences and genetic parameters for body composition traits in beef cattle. J. Anim. Sci. 72: 2745-2755.

Mascioli AS, Alencar MM, Barbosa PF, Novaes AP, et al. (1996). Estimativas de parâmetros genéticos e proposição de critérios de seleção para pesos na raça Canchim. Rev. Bras. Zootec. 25: 72-82.

Meirelles SL, Espasandin AC, Mattar M and Queiroz SA (2009). Genetic and environmental effects on sexual precocity traits in Nelore cattle. Rev. Bras. Zootec. 38: 1488-1493 http://dx.doi.org/10.1590/S1516-35982009000800012.

Meirelles SL, Alencar MM, Oliveira HN and Regitano LCA (2010). Efeitos de ambiente e estimativas de parâmetros genéticos para características de carcaça em bovinos da raça Canchim criados em pastagem. Rev. Bras. Zootec. 39: 1437-1442 http://dx.doi.org/10.1590/S1516-35982010000700006.

Plummer M, Best N, Cowles K and Vines K (2006). CODA: Convergence Diagnosis and Output Analysis for MCMC. RNews 6: 7-11.

R Development Core Team (2012). R: a language and environment for statistical computing. Available at [http://www.Rproject.org]. Accessed March 10, 2012.

Reverter A, Johnston DJ, Graser HU, Wolcott ML, et al. (2000). Genetic analyses of live-animal ultrasound and abattoir carcass traits in Australian Angus and Hereford cattle. J. Anim. Sci. 78: 1786-1795.

Rubiano AGG, Arrigoni MB, Martins CL, Rodrigues E, et al. (2009). Desempenho, características de carcaça e qualidade da carne de bovinos superprecoces das raças Canchim, Nelore e seus mestiços. Rev. Bras. Zootec. 38: 2490-2498 http://dx.doi.org/10.1590/S1516-35982009001200027.

SAS (2010). SAS user's guide. Version 9.3.SAS Institute, Cary NC.

Utrera AR and Van Vleck LD (2004). Heritability estimates for carcass traits of cattle: a review. Genet. Mol. Res. 3: 380394.

Yokoo MJ, Albuquerque LG, Lôbo RB, Bezerra LAF, et al. (2008). Genetic and environmental factors affecting ultrasound measures of longissimus muscle area and backfat thickness in Nelore cattle. Livest. Sci. 117: 147-154. http://dx.doi. org/10.1016/j.livsci.2007.12.006

Zuin RG, Buzanskas ME, Caetano SL, Venturini GC, et al. (2012). Genetic analysis on growth and carcass traits in Nelore cattle. Meat Sci. 91: 352-357. http://dx.doi.org/10.1016/j.meatsci.2012.02.018 